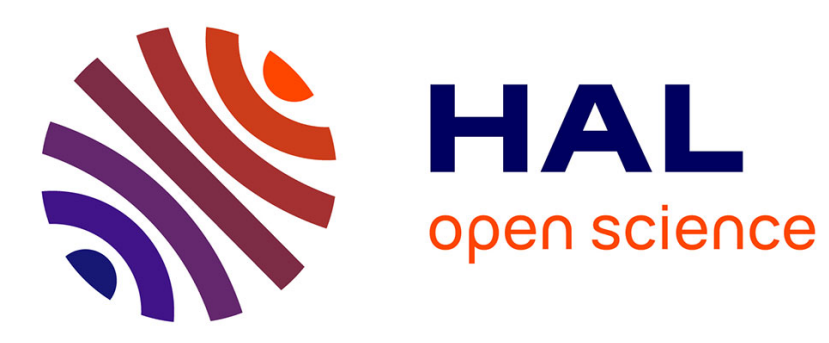

\title{
Comparative study on synteny between yeasts and vertebrates
}

Guénola Drillon, Fischer Gilles

\section{To cite this version:}

Guénola Drillon, Fischer Gilles. Comparative study on synteny between yeasts and vertebrates. Comptes Rendus Biologies, 2011, 334 ((8-9)), pp.629-638. 10.1016/j.crvi.2011.05.011 . hal-00626818

\section{HAL Id: hal-00626818 https://hal.science/hal-00626818}

Submitted on 27 Sep 2011

HAL is a multi-disciplinary open access archive for the deposit and dissemination of scientific research documents, whether they are published or not. The documents may come from teaching and research institutions in France or abroad, or from public or private research centers.
L'archive ouverte pluridisciplinaire HAL, est destinée au dépôt et à la diffusion de documents scientifiques de niveau recherche, publiés ou non, émanant des établissements d'enseignement et de recherche français ou étrangers, des laboratoires publics ou privés. 


\title{
Comparative study on synteny between yeasts and vertebrates
}

\section{Etude comparative de la synténie chez les levures et chez les vertébrés}

\author{
Guénola Drillon and Gilles Fischer*
}

Laboratoire de génomique des microorganismes, CNRS FRE3214, Université Pierre et Marie Curie, Institut des Cordeliers, 15 rue de l'école de médecine, 75006 Paris, France.

* corresponding author

Phone: +33144278139

Fax:: +3314427 7336

Email: gilles.fischer@upmc.fr 


\begin{abstract}
We computed the regions of conserved synteny between pairwise combinations amongst 13 vertebrate and 18 yeast genomes to perform a combined analysis of the evolution of chromosome maps in yeasts and vertebrates. In vertebrates, the number of conserved synteny blocks exponentially increases along with the protein divergence while concomitantly; the number of genes per block exponentially decreases. In yeasts, the same trends are found but when protein divergence exceeds $36 \%$, the number of blocks gradually decreases. For comparable evolutionary distances, vertebrate genomes are 6 to 8-fold more rearranged than yeast genomes. The rate of rearrangements is 3.1-fold higher in vertebrates than in yeasts, and is estimated to be of 2 rearrangements/Myr. However, when normalized by genome sizes, both the numbers and the rates of rearrangements per $\mathrm{Mb}$ are much higher in yeast than in vertebrate genomes.
\end{abstract}

Keywords: yeast, vertebrate, synteny, genome, evolution, chromosome, rearrangements

\title{
RESUME
}

Nous avons calculé les régions de conservation de synténie entre toutes les combinaisons deux à deux de 13 génomes de vertébrés et de 18 génomes de levures dans le but de fournir une analyse combinée de l'évolution des cartes chromosomiques chez les levures et chez les vertébrés. Chez les vertébrés, le nombre de locs de synténie augmente exponentiellement avec la divergence entre protéines orthologues, alors que le nombre de gènes par bloc diminue de manière concomitante. Chez les levures on observe les mêmes tendances mais lorsque la divergence protéique dépasse 36\%, le nombre de blocs diminue graduellement. Pour des distances évolutives comparables, les génomes des vertébrés sont 6 à 8 fois plus réarrangés que les génomes des levures. Le taux de réarrangement est 3,1 fois plus élevé chez les vertébrés que chez les levures et correspond à une valeur de 2,0 réarrangements/Ma. Cependant, lorsque l'on normalise ces valeurs par les tailles de génomes, à la fois les nombres et les taux de réarrangements sont beaucoup plus élevés dans les génomes de levures que dans les génomes de vertébrés.

Mots clés: levures, vertébrés, synténie, génome, évolution, chromosome, réarrangements 